\title{
Intention Model Analysis of Bogor Society against Pension Fund in Retirement Planning
}

\author{
Putri Putu Pratami $^{1^{*}}$, Budi Suharjo ${ }^{2}$, Endar Hasafah Nugrahani ${ }^{3}$ \\ Magister of Applied Mathematics, Faculty of Mathematics and Natural Science, Bogor Agricultural University, \\ Bogor, Indonesia
}

*Corresponding Author: Putri Putu Pratami, Magister of Applied Mathematics, Faculty of Mathematics and Natural Science, Bogor Agricultural University, Bogor, Indonesia

\begin{abstract}
Indonesia has a high workforce. Central Bureau of Statistics Indonesia released the workforce as of February 2016 which is 120,647,697 people from the total workforce of 127.671869 people, which means the Indonesian workforce reached $94.50 \%$. However, only $6.16 \%$ of Indonesia's workforce has not had a retirement plan. The purpose of this research is to identify the factors that influence the intention of Bogor society towards the retirement planning and to build the model of causality of retirement planning of Bogor City with Theory of Planned Behavior. Sampling technique used is simple random sampling, cluster sampling, and systematic sampling then processed with structural equation model (SEM). The result of this research is only $26 \%$ of respondents have pension fund. The indicator variables BB2, SN3, SN4, SN5, MTC2, and MTC3 are not able to validate each of the latent variables. The reliability result shows that SN, MTC, and ITU variables cannot be said to be reliable. Hypothesis test of latent variables shows that only the subjective norms have a significant effect on the intention of retirement planning.
\end{abstract}

Keywords: Structural Equation Modeling, Theory of Planned Behavior, Pension Fund, Retirement Planning

\section{INTRODUCTION}

Indonesia has a high workforce. Central Bureau of Statistics (BPS) released the workforce as of February 2016 which is $120,647,697$ people from the total workforce of 127.671 .869 people, which means the Indonesian workforce reached $94.50 \%$. Everyone should not only thinking about welfare while working but also thinking about the retirement welfare. As time passes, the necessities of life will get bigger but someone's ability to do things becomes less and less. This is the reason for the importance of preparing investment and financial problems in old age. The sufficient wealth, healthy, and financially free is what everyone wants when facing retirement. Investments help one to prepare for a quality pension because the cost of living over time continues to grow. The government still can not provide old-age insurance to all people who have entered retirement. It becomes one of the reasons one should think about oneself, both in productive and retirement. Therefore, one must prepare all the necessities to face retirement. One of the investment that guarantee the retirement is the Pension Fund.

Pension Fund, the government considers that national development is needed to collect and manage the Fund in order to maintain the continuity of income in the old days in order to realize social justice for all Indonesian people. The Pension Fund is a means of raising funds to improve the welfare of its participants and increase the participation of the community in preserving the increasing and sustainable national development and ensuring the holding of Pension Fund can also increase the motivation, the working calm to increase productivity, and improve the prosperity.

Public awareness of the importance of planning in the old days still need to be grown. The Financial Services Authority (OJK) publishes Pension Fund Statistic report 2014 and 2015. The participant of Dana Pensiun 2015 is 4,189,527 people or an increase of $6.30 \%$ from 2014 of 264,083 people. Based on BPS data in August 2015, 68,036,477 workforce, so that the number of pension fund participant in 2014 on the number of Indonesian workers nationwide is only $6.16 \%$. This figure is still very far from the hope of remembering there are $93.84 \%$ more people who have not become participants of the Pension Fund (OJK 2015). Penetration of Pension Fund participants in 2011 - 2015 can be seen in Table 1. 
Table1. Penetration of pension fund participant in 2011 - 2015

\begin{tabular}{|c|c|c|c|c|c|}
\hline \multirow{2}{*}{ Description } & \multicolumn{5}{|c|}{ Year } \\
\hline & 2011 & 2012 & 2013 & 2014 & 2015 \\
\hline Number of Indonesian workers & 60.905 .202 & 62.605 .346 & 64.192 .990 & 67.045 .437 & 68.036 .477 \\
\hline $\begin{array}{l}\text { Number of the penson fund } \\
\text { participants }\end{array}$ & 3.082 .708 & 3.345 .798 & 3.633 .645 & 3.925 .444 & 4.189 .527 \\
\hline Penetration $(\%)$ & $5.06 \%$ & $5,34 \%$ & $5,66 \%$ & $5,85 \%$ & $6,16 \%$ \\
\hline
\end{tabular}

Penetration of Pension Fund participants from 2011 to 2015 is seen to increase. However, the penetration of the number of participants of the Pension Fund to the number of workers is still far as expected. People's knowledge of the Pension Fund as one of the financial institutions in Indonesia is still very low compared to other financial institutions, such as banks, insurance companies, and finance companies (Ministry of Finance 2012). It becomes a major task of the government in the development of Pension Fund industry. The government should know thereasons Indonesians have little interest in the Pension Fund. One of the methods to know the public interest in the Pension Fund is the theory of planned behavior by Icek Ajzen (1985). Theory of planned behavior is a theory that predicts behavior because behavior can be planned and considered. Looking at the phenomenon, it is necessary to identify the factors of intention of the people of Bogor City to the Pension Fund. The identification needs to be formulated in the form of mathematical model in order to facilitate in digging information about society preparation level of Bogor City to its old age. Intention and usage behavior in retirement is influenced by attitude toward behavior, norm subjective and perceived behavioral control. The measuring instrument used in this research is Structural Equation Model (SEM). The purpose of this research is to identify the factors that influence the intention of the people of Bogor City towards the planning of retirement and to build the model of causality of old age community planning of Bogor City with Theory of Planned Behavior.

The study of theory planned behavior and retirement planning is also reviewed by Dam et al. (2009), Topa et al. (2009), Griffin et al. (2012), Mohidin et al. (2013), Purnamasari (2014), Koposko et al. (2015), and Amelia et al. (2017). However, their research only predicts direct indicaor variables on the theory of planned behavior. Amelia et al (2017) reviewed on old-age financial ownership of Bogor City workers, Purnamasari (2014) concerning retirement planning and its effect on the subjective economic welfare of retirement families, Griffin et al. (2012) reviewed about developng and testing models to identify retirement panning based on theory planned of behavior, and Topa et al. (2009) analyzed retiremen planning behavior and retirement statisfication. Amelia et al (2017) analyzed the influence of attitudes toward behavior, subjective norms, and behavioral control over ownership of old-age financial planning in Bogor City workers as well as analyzing demographic characteristics of Bogor City workers who have retirement planning using the corelation test dan binary logistic regression. Amelia et al. (2017) analyzed direct indicator variables on the theory of planned behavior. Purnamasari (2014) analyzed the behavior of retirement planning conducted by respondents in the past and analyzed the influence of work history, length of education towards retirement planning. The results of research by Griffin et al. (2012) said that attitudes toward behavior, behavioral control, and subjective norms had a significant effect on workers in retirement planning. Mohidin et al. (2013) analyzed the relationship between attitude towards personal financial planning and retirement planning behavior among workers in Kinabalu. Koposko et al. (2015) analyzed the impact of interpersonal perception on saving behavior for retirement. The study of retirement planning and financial literacy was reviewed by Joo and Grable (2005), Lusardi and Mitchell (2007a; 2007b;2008;2010), Lusardi et al. (2010), Croy et al. (2010a), Klapper and Panos (2011), Rooji et al. (2011), Mehdzan and Tabiani (2013), Agnew et al. (2013), Liman and Hananto (2009), Cucinelli et al. (2009), Kimiyaghalam et al. (2017), and Selvadurai et al. (2018).

\section{STUdy OF Literature}

\subsection{Theory of Planned Behavior}

Theory of planned behavior is a theory developed by Icek Ajzen in 1985. The theory is the development of reason action theory made by Ajzen and Fishben in 1975. The theory of planned behavior has the purpose of predicting and explaining human behavior in certain contexts. The main focus of the theory of planned behavior is the same as the reason action theory, namely the intention of individuals to perform certain behaviors 


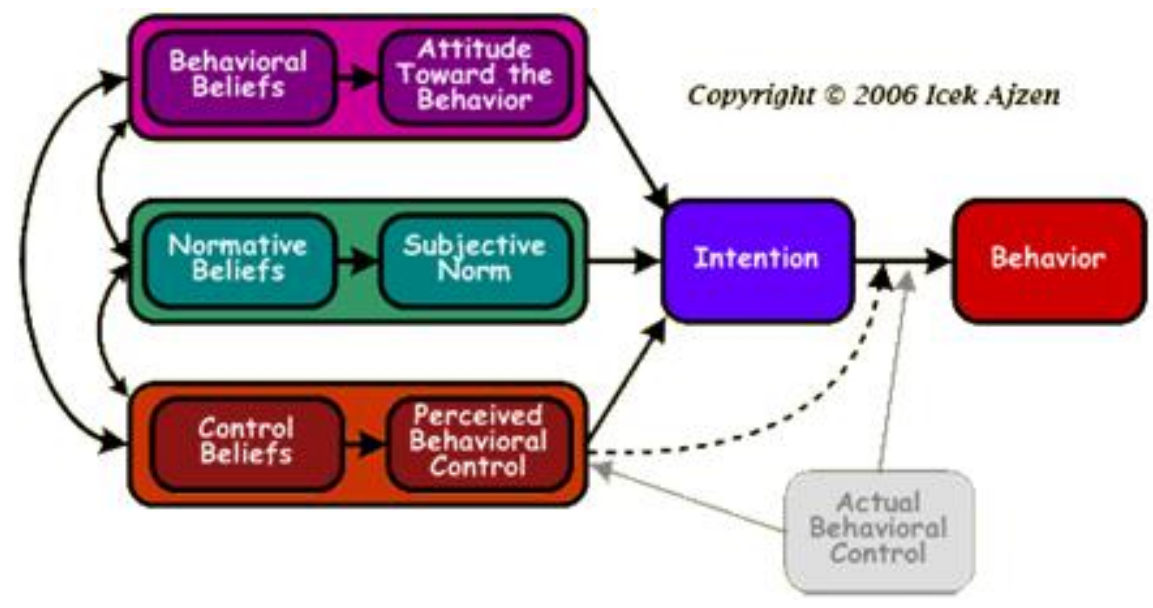

Figure. Theory of Planned behavior Frame(Ajzen 2005)

\subsection{Intention to Use}

Intention according to Ajzen and Fishbein (1991) is assumed to be a motivational factor that influences behavior. As a general rule, the stronger the intention to engage in behavior, the more likely it is to have to show or do the behavior.Whereas according to Bandura (1988) intention to use is a full determination to carry out certain activities or produce a situation in the future. In general, if an individual has the intention to perform a behavior then the individual will tend to do that behavior, whereas if it does not have the intention to perform a behavior that individuals are not inclined to do so.

Ajzen and Fishbein (1975) suggest that there are several stages of measuring intention to use, namely: (1) defines individual behavior that will be examined based on targets, actions, time and situation, (2) determine the study population, (3) formulate the things that will be used on the measuring instrument.

\subsection{Attitude towards Behavior}

Attitude towards behavior according to Ajzen (2005) is the degree of an individual's positive or negative assessment of a behavior. The attitude towards a behavior that is determined by the belief is called behavioral beliefs, namely the individual's belief about the consequences obtained from doing a positive and negative behavior. The attitude towards a behavior in the planned of behavior theory is determined by a combination of individual belief in the positive or negative consequences of carrying out a behavior with the individual's subjective value towards the consequences of behaving.

In general, the more individuals have an assessment that behavior will produce positive consequences then the individual will tend to be favorable towards the behavior. However, if an individual has an assessment that a behavior will produce negative consequences, then the individual will tend to be unfavorable to the behavior (Ajzen 2005).

\subsection{Subjective Norm}

Ajzen (2005) argues that subjective norms are functions based on belief which are referred to as normative beliefs, namely beliefs about agreement and or disagreement of a person or group that are important for individuals to a behavior (salient referent beliefs). Approval or disapproval comes from referents or other people who influence the individual (significant others) such as family, spouse, coworkers, and co-workers.

Subjective norms according to Ajzen (2005) are individual perceptions of social pressure to do or not to conduct a behavior. Subjective norms are determined by a combination of individual beliefs about agreement and or disagreement of a person or group that is important for the individual towards normative beliefs with the individual's motivation to comply with the reference (motivation to comply).

\subsection{Perceive Behavioral Control}

According to Ajzen (2005) perceived behavioral control is an individual's perception of the ease or difficulty of carrying out certain behaviors. Ajzen (2005) suggested that perceived behavioral control 
is a function based on beliefs called control beliefs, namely individual beliefs about the existence or absence of supporting factors or individual barriers to bring about a behavior (salient control beliefs). Belief about these factors is based on an individual's previous experience of a behavior, information related to a behavior obtained by an individual by observing knowledge possessed by himself or others known to the individual, and various other factors that influence individual feelings about the level of difficulty in doing something. behavior.

In general, the more individuals feel a lot of supporting factors and fewer obstructive factors in carrying out a behavior, then the individual will tend to assume easy behavior in him, while the fewer individuals feel a little supportive factors and many inhibiting factors, then individuals tend to assume difficult behavior on him (Ajzen 2005). Perceived behavioral control is expected to moderate the influence of intentions on behavior carried out by individuals. If the perceived control of the individual is strong and an intention possessed by a strong individual, then the individual will produce behavior (Ajzen, 2005).

\subsection{Structural Equation Modelling}

Structural Equation Model (SEM) is a model used to measure the relationship between latent variables (Hair et al. 2014). Structural equation model according to Hair et al. (1998) is a multivariate technique that combines aspects of multiple regression and factor analysis by estimating a series of interdependent relationships that are interrelated simultaneously. SEM consists of 2 parts, namely the latent variable model and the measurement model (Ghozali, 2008). The first part is a latent variable model that is a variable that is not directly measured. While the second part is a measurement model, which describes several indicators or some measured variables as effects or reflections of the latent variables.

Latent variables are unobservable variables or cannot be measured directly. However, latent variables can be represented or measured by one or more other variables, namely indicator variables (Hair et al. 1998). There are two types of latent variables in SEM that are endogenous and exogenous. Endogenous latent variables are non-free latent variables in one model. Exogenous latent variables are latent variables that act as independent variables in the model.

According to Hair et al. (1998) there are seven steps in the structural equation model, namely (1) developing a theory-based model, (2) constructing a construct, (3) changing the path diagram into a structural equation and a measurement equation, (4) choosing the type of matrix and estimating the model to be proposed, (5) estimating identification on structural models, (6) evaluating results on goodness of fit, (7) interpretation and modification of the model if it is correct in theory.

\section{RESEARCH METHODS}

The location of this study is the city of Bogor. The study was conducted from May 2017 to November 2017. Sampling methods used in this study were cluster sampling, simple random sampling, and systematic random sampling. The population of this study is the people of Bogor City who are already working. The sample in this study is the head of the family in the city of Bogor. The number of samples used in this study is 100 people.

The steps of data analysis in this research are:

- Identify the problem.

- Create indicators that fit the theory of planned behavior, design the questionnaire, and spread the questionnaire.

- Descriptive analysis

Descriptive analysis in this study aims to see the characteristics of respondents in general ie sex, age, last education status, occupation, length of work, the number of family dependents, monthly income, monthly expenses, pension fund ownership and type of pension fund.

- Analysis with structural equation model.

$>$ Stage 1 of SEM is to develop a model based on the theory in this research is to make an indicator in accordance with the theory of planned behavior and apply the model on the whole sample. Operational variables can be seen in Table 2.

$>$ Stage 2, after the model is designed based on theory, the next step is to build a cross diagram. Cross diagram in this study can be seen in Figure 2. 
Stage 3 of SEM that is converting path diagram; making path diagram into model of structural equation and model of measurement equation. The model of structural equation in this study can be seen in equations (1) and (2) whereas the model of measurement equation can be seen in equations (3) and (4). The formation and processing of SEM models was analyzed with Lisrel 8.72 applications.

$>$ Stage 4, the method used to estimate the model parameters is the maximum likelihood method.

$>$ Stage 5 , the expected identification in this research is having $\mathrm{db}=0$ or $\mathrm{db}>0$. How to identify the model is:

$$
\mathrm{db}=\frac{1}{2}[(\mathrm{p}+\mathrm{q})(\mathrm{p}+\mathrm{q}+1)]-\mathrm{t}
$$

information:

$\mathrm{p}=$ number of variables of endogenous indicator on model,

$\mathrm{q}=$ number of exogenous indicator variables in the model,

$\mathrm{t}=$ number of model coefficients to be estimated

$>$ In stage 6, the model conformity evaluation is performed by testing the suitability of the model (smallest possible $\chi^{2}$ values, $p$ value $>0.05$, RMSEA value $\leq 0.08$, GFI $\geq 0.90$, AGFI $\geq 0.80, \mathrm{NFI} \geq 0.90, \mathrm{CFI} \geq 0.90$ ), and evaluation of predicted results is done by analyzing the measurement model that is reliability test $\left(\mathrm{CR}=\frac{\left(\sum \lambda_{\mathrm{i}}\right)^{2}}{\left(\sum \lambda_{\mathrm{i}}\right)^{2}+\sum \mathrm{e}_{\mathrm{i}}}\right)$ and validity test $\left(\left(\mathrm{VE}=\frac{\left(\sum \lambda_{\mathrm{i}}^{2}\right)}{\left(\sum \lambda_{\mathrm{i}}^{2}\right)+\sum \mathrm{e}_{\mathrm{i}}}\right)\right.$ of the standardized loading faktor $\left(\lambda_{\mathrm{i}}\right)$ and the measurement error value $\left(e_{i}\right)$

$>$ In stage 7, the model's interpretation is to determine possible models to improve the theoretical explanation or goodness of fit.

\subsection{Indicator Variable}

Outcome evaluations $\left(\xi_{1}\right)$

\begin{tabular}{|l|l|c|}
\hline \multicolumn{1}{|c|}{ Description of Indicator Variables } & Indicator & Symbol \\
\hline Increasing knowledge about pension funds is a good thing & OE1 & $x_{1}$ \\
Having a pension fund to ensure welfare in the retirement is a good thing & OE2 & $x_{2}$ \\
Setting aside some salary to have a pension fund is a good thing & OE3 & $x_{3}$ \\
Trying to work harder to have a pension fund is a good thing & OE4 & $x_{4}$ \\
\hline
\end{tabular}

Behavioral beliefs $\left(\xi_{2}\right)$

\begin{tabular}{|l|c|c|}
\hline \multicolumn{1}{|c|}{ Description of Indicator Variables } & Indicator & Symbol \\
\hline Retirement planning may help improve the knowledge of pension funds & $\mathrm{BB} 1$ & $x_{5}$ \\
Retirement planning may help improve the knowledge of pension funds & $\mathrm{BB} 2$ & $x_{6}$ \\
Retirement planning age may help set aside some salary to have a pension fund & $\mathrm{BB} 3$ & $x_{7}$ \\
Retirement planning age may help to work harder to have a pension fund & $\mathrm{BB} 4$ & $x_{8}$ \\
\hline
\end{tabular}

\section{Normative beliefs $\left(\xi_{3}\right)$}

\begin{tabular}{|l|c|c|}
\hline \multicolumn{1}{|c|}{ Description of Indicator Variables } & Indicator & Symbol \\
\hline Families require to have pension funds in retiremen planning & NB1 & $x_{9}$ \\
Relatives require to have pension funds in retiremen planning & NB2 & $x_{10}$ \\
Coworkers require to have pension funds in retiremen planning & NB3 & $x_{11}$ \\
\hline
\end{tabular}

Motivation to Comply $\left(\xi_{4}\right)$

\begin{tabular}{|l|l|c|}
\hline \multicolumn{1}{|c|}{ Description of Indicator Variables } & Indicator & Symbol \\
\hline Families have an influence in deciding to have a pension fund & MTC1 & $x_{12}$ \\
Relatives have an influence in determining the decision to have a pension fund & MTC2 & $x_{13}$ \\
Coworkers have an influence in determining the decision to have a pension fund & MTC3 & $x_{14}$ \\
\hline
\end{tabular}

Control Beliefs $\left(\xi_{5}\right)$

\begin{tabular}{|l|c|c|}
\hline \multicolumn{1}{|c|}{ Description of Indicator Variables } & Indicator & Symbol \\
\hline There are unexpected problems like demands in life & CB1 & $x_{15}$ \\
Feeling sick, tired, listless & CB2 & $x_{16}$ \\
There is a duty to the family asking for unexpected things in life & CB3 & $x_{17}$ \\
There are unexpected demands on work or workplace & CB4 & $x_{18}$ \\
\hline
\end{tabular}


Intention Model Analysis of Bogor Society against Pension Fund in Retirement Planning

\begin{tabular}{|c|c|c|}
\hline There are unexpected financial problems in life & CB5 & $x_{19}$ \\
\hline \multicolumn{3}{|l|}{ Perceived of Control Beliefs $\left(\xi_{6}\right)$} \\
\hline Description of Indicator Variables & Indicator & Symbol \\
\hline $\begin{array}{l}\text { Unexpected problems such as demands in life make it more difficult to have a } \\
\text { pension fund }\end{array}$ & POCB1 & $x_{20}$ \\
\hline Feeling sick, tired, lethargic makes it harder to have a pension fund & POCB2 & $x_{21}$ \\
\hline $\begin{array}{l}\text { Responsibility on the family asking for unexpected things make it more difficult to } \\
\text { have a pension fund }\end{array}$ & POCB3 & $x_{22}$ \\
\hline $\begin{array}{l}\text { Unexpected demands on work or workplace make it more difficult to have a pension } \\
\text { fund }\end{array}$ & POCB4 & $\begin{array}{l}x_{23} \\
x_{24}\end{array}$ \\
\hline $\begin{array}{l}\text { The unexpected demands of financial problems in life will make it more difficult to } \\
\text { have a pension fund }\end{array}$ & POCB5 & \\
\hline
\end{tabular}

\section{Attitude Towards Behavior $\left(\xi_{7}\right)$}

\begin{tabular}{|l|c|c|}
\hline \multicolumn{1}{|c|}{ Description of Indicator Variables } & Indicator & Symbol \\
\hline Retirement planning with pension funds is a good decision & ATB1 & $x_{25}$ \\
Retirement planning with pension funds is something that needs to be decided & ATB2 & $x_{26}$ \\
Retirement planning with pension funds is an important thing to decide & ATB3 & $x_{27}$ \\
Retirement planning with pension funds is a useful decision & ATB4 & $x_{28}$ \\
\hline
\end{tabular}

\section{Subjectif Norm $\left(\xi_{8}\right)$}

\begin{tabular}{|l|c|c|}
\hline \multicolumn{1}{|c|}{ Description of Indicator Variables } & Indicator & Symbol \\
\hline There are others who require to join the Pension Fund & SN1 & $x_{29}$ \\
There are important people like family and relatives have pension funds & SN2 & $x_{30}$ \\
People who interact daily have pension funds & SN3 & $x_{31}$ \\
The majority of people whose opinions are taken into account will receive plans to & SN4 & $x_{32}$ \\
have a pension fund & SN5 & $x_{33}$ \\
Having a pension fund can make a pioneer in retirement planning &
\end{tabular}

\section{Perceived behavioral control $\left(\xi_{9}\right)$}

\begin{tabular}{|l|c|c|}
\hline \multicolumn{1}{|c|}{ Description of Indicator Variables } & Indicator & Symbol \\
\hline having a Pension Fund is easy to do & PBC1 & $x_{34}$ \\
have a Pension Fund easily owned & PBC2 & $x_{35}$ \\
Having a pension fund in old age planning is easy to decide & PBC3 & $x_{36}$ \\
\hline
\end{tabular}

\section{Intention to $\operatorname{Use}\left(\eta_{1}\right)$}

\begin{tabular}{|l|c|c|}
\hline Description of Indicator Variables & Indicator & Symbol \\
\hline Retirement planning with pension funds to ensure old age may be planned & ITU1 & $y_{1}$ \\
Retirement planning with pension funds may be sought & ITU2 & $y_{2}$ \\
Interest to have a pension fund in retirement planning & ITU3 & $y_{3}$ \\
\hline
\end{tabular}

The framework of the research model can be seen in the following figure:

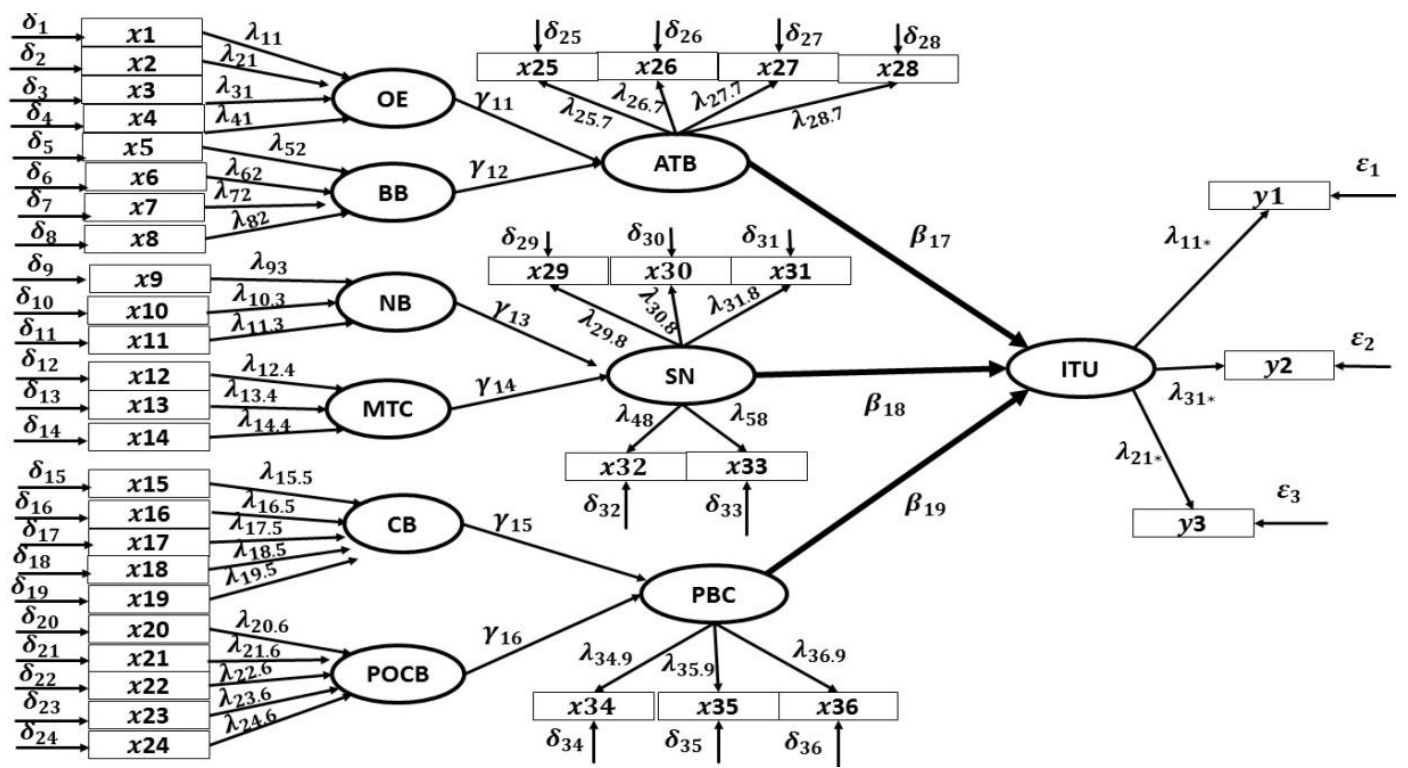

Figure2. Theory of planned behavior in the structural equation model 
The model can be written in the following equation:

Structural equations in the form of matrix:

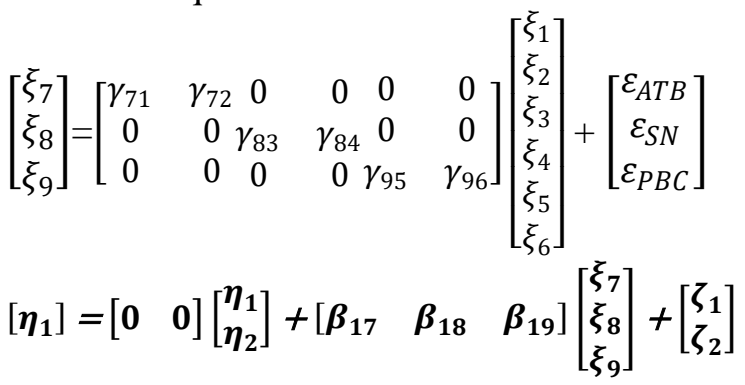

Measurement model in this research are:

$$
\left[\begin{array}{l}
y_{1} \\
y_{2} \\
y_{3}
\end{array}\right]=\left[\begin{array}{ll}
\lambda_{11 *} & 0 \\
\lambda_{21 *} & 0 \\
\lambda_{31 *} & 0
\end{array}\right]\left[\begin{array}{l}
\eta_{1} \\
\eta_{2}
\end{array}\right]+\left[\begin{array}{l}
\varepsilon_{1} \\
\varepsilon_{2} \\
\varepsilon_{3}
\end{array}\right]
$$

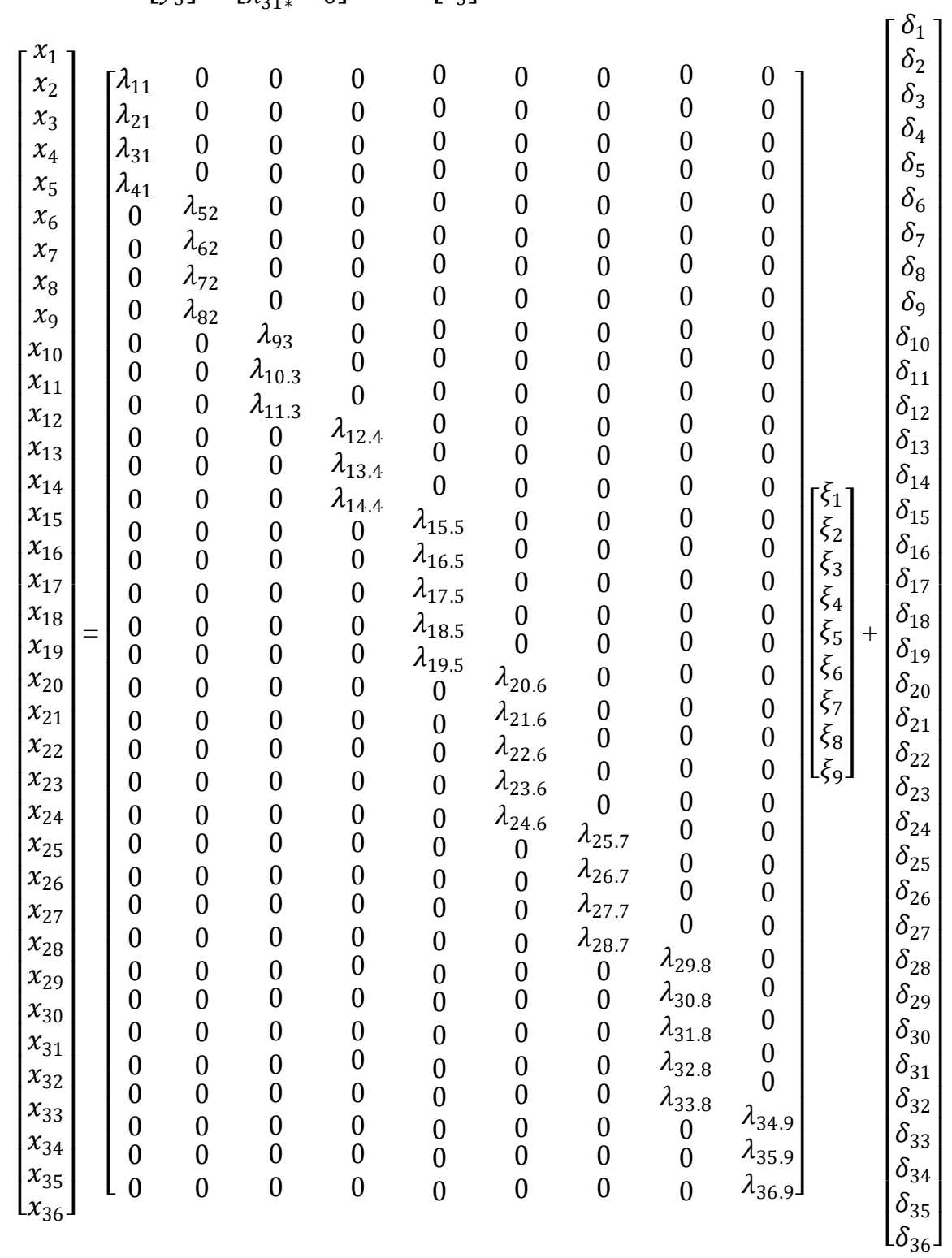

\section{RESULTS AND DISCUSSION}

\subsection{Respondent Characteristics}

Respondents in this study have various characteristics. The respondents' gender in this study was mostly male. That was $84 \%$. It is because the respondents in this study is the head of household as the highest policy holder of the family. The lowest age of respondents was 24 and the highest was 63 years. As many as $84 \%$ of respondents did not finish their education until college. The majority of 
respondents work as private employees that is as much as $46 \%$ and entrepreneurs as much as $29 \%$. The number of dependents of the families of respondents at most is 3 people as much as $28 \%$. the distribution of gross income per month of respondents is in the range below Rp500 000 - above Rp12 500 000. However, only $17 \%$ of respondents had an income above Rp7 500 000. The average saving of respondents is Rp495,000. The average savings of Bogor city's largest citizens are respondents aged 46 - 55 amounting to Rp 1368181 . At this age the respondent prepares more savings because it is the age that is closest to retirement and anticipates early retirement. At this age is the peak period of independence, namely the period of enjoying the results of investment and enjoying the results of investment and enjoying a career and business (Gilbert and Kahl 1992). In general, indviduals have the motivation to save (Abrahamse and Steg 2009). The largest average savings is in the last educated respondents graduated S1 or higher, amounting to Rp 2773 333. Based on these results, it can be concluded that the higher the respondents' last education, the higher of respondents' average saving will be. This is consistent with Lusardi (2003) and Joo and Grable (2005), the level of education influences a person in retirement planning.

\subsection{Pension Fund Ownership}

Old-age investment is only owned by 26 respondents. The ownership of pension funds or old age investment is dominated by respondents aged 46-55 (57.69\%, 15 of 26 people). Ownership of pension funds in respondents aged $26-35$ years is $30.77 \%$ ( 8 of 26 people) and respondents aged $56-64$ years is $11.54 \%$ ( 3 of 26 people). The ownership of pension fund or old age investment is dominated by Bogor City people who have the last education graduated from S1 or higher that is $46 \%$ (12 of 26 people). Bogor City people who have retirement funds feel like to have other pension funds for the elderly. The reason they want to have other types of pensions is to have knowledge of the products of pension funds, pension fund products in accordance with the required, relatively affordable pension fund products, and pension fund products easily available.

\section{TheORY OF PlanNed BeHAVIOR}

\section{Attitude Towards Behavior}

\begin{tabular}{|l|c|c|c|c|}
\hline Indicator & Disagree & Between Agree and disagree & Agree & Average \\
\hline ATB1 & $4.05 \%$ & $37.84 \%$ & $58.11 \%$ & 3.86 \\
\hline ATB2 & $1.35 \%$ & $37.84 \%$ & $60.81 \%$ & 3.96 \\
\hline ATB3 & $1.35 \%$ & $40.54 \%$ & $58.11 \%$ & 3.92 \\
\hline ATB4 & $0.00 \%$ & $28.38 \%$ & $71.62 \%$ & 3.92 \\
\hline
\end{tabular}

\section{Outcome Evaluations}

\begin{tabular}{|l|c|c|c|c|}
\hline IndicatorVariables & Bad & Between bad and good & Good & Average \\
\hline OE1 & $2.70 \%$ & $43.24 \%$ & $54.05 \%$ & 3.85 \\
\hline OE2 & $1.35 \%$ & $35.14 \%$ & $63.51 \%$ & 4.05 \\
\hline OE3 & $2.70 \%$ & $43.24 \%$ & $54.05 \%$ & 3.85 \\
\hline OE4 & $1.35 \%$ & $44.59 \%$ & $54.05 \%$ & 3.86 \\
\hline
\end{tabular}

Behavioral Beliefs

\begin{tabular}{|l|c|c|r|c|}
\hline IndicatorVariables & Impossible & Beween Possible and impossible & Possible & Average \\
\hline BB1 & $14.86 \%$ & $13.51 \%$ & $44.59 \%$ & 3.47 \\
\hline BB2 & $14.48 \%$ & $44.59 \%$ & $40.54 \%$ & 3.36 \\
\hline BB3 & $19.92 \%$ & $48.65 \%$ & $3.43 \%$ & 3.24 \\
\hline BB4 & $13.51 \%$ & $39.19 \%$ & $47.30 \%$ & 3.51 \\
\hline
\end{tabular}

Subjective Norms

\begin{tabular}{|l|c|c|c|c|}
\hline IndicatorVariables & Disagree & Between Agree and disagree & Agree & Average \\
\hline SN1 & $32.43 \%$ & $37.84 \%$ & $29.73 \%$ & 3.16 \\
\hline SN2 & $36.49 \%$ & $41.89 \%$ & $21.62 \%$ & 2.93 \\
\hline SN3 & $54.05 \%$ & $31.08 \%$ & $14.86 \%$ & 2.66 \\
\hline SN4 & $33.78 \%$ & $43.24 \%$ & $22.97 \%$ & 2.96 \\
\hline SN5 & $41.89 \%$ & $47.30 \%$ & $10.81 \%$ & 2.70 \\
\hline
\end{tabular}


Normative Beliefs

\begin{tabular}{|l|c|c|c|c|}
\hline Indicator & Do not have pension fund & Between have and do not have & Have a pension fund & Average \\
\hline NB1 & $24.32 \%$ & $39.19 \%$ & $36.48 \%$ & 3.35 \\
\hline NB2 & $43.24 \%$ & $36.49 \%$ & $20.27 \%$ & 2.85 \\
\hline NB3 & $45.94 \%$ & $32.43 \%$ & $21.62 \%$ & 2.84 \\
\hline
\end{tabular}

\section{Motivation to Comply}

\begin{tabular}{|l|c|c|c|c|}
\hline Indicator & No efect & Between take effect and no effect & Take effect & Average \\
\hline MTC1 & $18.92 \%$ & $37.84 \%$ & $43.24 \%$ & 3.46 \\
\hline MTC2 & $43.24 \%$ & $25.68 \%$ & $31.08 \%$ & 2.97 \\
\hline MTC3 & $56.75 \%$ & $27.03 \%$ & $16.62 \%$ & 2.61 \\
\hline
\end{tabular}

Perceived Behavioral Control

\begin{tabular}{|l|c|c|c|c|}
\hline Indicator & Difficult & Between easy and difficult & Easy & Average \\
\hline PBC1 & $72.97 \%$ & $13.51 \%$ & $12.51 \%$ & 2.34 \\
\hline PBC2 & $39.19 \%$ & $40.54 \%$ & $20.27 \%$ & 2.86 \\
\hline PBC3 & $8.11 \%$ & $55.41 \%$ & $36.49 \%$ & 3.51 \\
\hline
\end{tabular}

Control Beliefs

\begin{tabular}{|l|c|c|c|c|}
\hline Indicator & Rarely & Between Often and rarely & Often & Average \\
\hline CB1 & $33.79 \%$ & $37.84 \%$ & $28.38 \%$ & 3.05 \\
\hline CB2 & $35.13 \%$ & $41.89 \%$ & $22.97 \%$ & 2.97 \\
\hline CB3 & $56.76 \%$ & $21.62 \%$ & $21.62 \%$ & 2.65 \\
\hline CB4 & $54.04 \%$ & $31.08 \%$ & $14.86 \%$ & 2.53 \\
\hline CB5 & $28.38 \%$ & $48.65 \%$ & $22.97 \%$ & 2.97 \\
\hline
\end{tabular}

Power of Control Beliefs

\begin{tabular}{|l|c|c|c|c|}
\hline Indicator & Incorret & Middle & Correct & Average \\
\hline POCB1 & $16.22 \%$ & $58.11 \%$ & $25.67 \%$ & 3.20 \\
\hline POCB2 & $13.51 \%$ & $66.22 \%$ & $20.27 \%$ & 3.15 \\
\hline POCB3 & $22.97 \%$ & $48.65 \%$ & $28.38 \%$ & 3.14 \\
\hline POCB4 & $13.51 \%$ & $62.16 \%$ & $24.33 \%$ & 3.19 \\
\hline POCB5 & $14.86 \%$ & $51.35 \%$ & $33.79 \%$ & 3.34 \\
\hline
\end{tabular}

\section{Intention to Use}

\begin{tabular}{|l|c|c|c|c|}
\hline Indicator & Disagree & Between Agree and Disagree & Agree & Average \\
\hline ITU1 & $31.08 \%$ & $41.89 \%$ & $27.03 \%$ & 2.82 \\
\hline ITU2 & $31.08 \%$ & $47.30 \%$ & $21.62 \%$ & 2.78 \\
\hline ITU3 & $26.49 \%$ & $41.89 \%$ & $21.62 \%$ & 2.65 \\
\hline
\end{tabular}

Attitude towards a behavior according to Ajzen (2005) is the degree of an individual's positive or negatve assessment of behavior. The attitude towards behavior that is determined by the belief is called behavioral beliefs, namely the individual's belief about the consequences obtained from doing a positive and negative behavior. In attitude toward behavior, $71.62 \%$ of respondents believe that planning of retirement with pension fund is a useful thing. In Indonesia, it is common for a child to take care of parents when they have retired. However, not many children are willing to support their parent's retirement lives for various reasons (Liman and Hananto 2009). They believe that elderly planning makes individuals do not burden other family members and feel comfortable living in old age (Amelia 2017). Although they do not have retirement funds, they believe that retirement planning with pension funds is a good thing, needs to be decided, important and useful. As many as $63.51 \%$ of respondents believe that having a pension fund to ensure the welfare of old age is a good thing. As a result, as many as $40.54 \%$ of respondents believe that preparing for the elderly can help them have a pension fund to ensure the welfare of retirement. This is consistent with the research of Mutran et al. (2007) and Noone et al. (2009) that pension planning can increase adjustment in retirement. Mohidin et al. (2003) say that attitudes toward individual financial planning have a positive relationship of retirement planning. As much as $54.05 \%$ of respondents believe that increasing knowledge about pension funds is a good thing. According to Lusardi and Mitchell (2007), someone with low financial literacy is less able to plan for retirement. Sufficient financial literacy can increase savings ownership for short-term financial planning and ownership of pension funds for long-term financial planning (Prawirz and Cohart 2014). The impact of individual financial literacy on retirement planning has 
been discusse by several authors, such as Cheng and Volpe (1998), Lusardi and Mitchell (2007a;2007b;2008;2011), Lusardi et al. (2010), filotto and Ncolini (2010), and Clark et al. (2012)

Subjective norms according to Ajzen (2005) are individual perceptions of social pressure to do or not to conduct a behavior. Subjective norms are one's perception of social pressure around to cpnduct behavior or not to do while attitude is a positive or individual evaluation of certain behaviors (Fishbein and Ajzen 1975). In the subjective norm, as many as $33.78 \%$ did not agree to the decision of respondents to have pension funds in the retirement planning. Families, relatives, and people who interact daily do not require the respondent to have a pension fund and will not have a pension fund if the respondent has a pension fund in the next few years. A total of $45.94 \%$ of respondents said that their colleagues thought they did not agree on their decision to have a pension fund for old age in the next few years. As a result, as many as $56.75 \%$ of respondents said the opinion of colleagues had no effect on their decision in choosing a form of pension fund investment for old age. This is not in accordance with Ajzen's (2006) statement that social referrals such as parents, partners, collegues, friends make high confidence in influencing a behavior.

Perceived behavioral control is the individual's perception of the control they have in relation to cenrtain behaviors (Ajzen 2005). Perceived behavioral control or behavioral control according to Ajzen (2005) is an individual's perception of the ease or difficulty of carrying out certain behaviors. In perceived behavioral control, $72.97 \%$ of respondents said that it is not easy to have a pension fund for old age in the next few years. Kim (2003) found that Asians tend to keep working when thet reach retirement age. Respondents found it impossible to have pension funds in old age planning even though the decision to have a pension fund was entirely up to them. A total of $56.76 \%$ of respondents rarely feel the responsibility of family to request unexpected things in their lives. As a result, as many as $28.38 \%$ of respondents find it more difficult having pension funds for old age if the obligations on the family ask for unexpected things in the next few years. In general, the more individuals feel a lot of supporting factors and fewer obstructive factors in carrying out the behavior, then the individual will tend to assume easy behavior in him, while the fewer individuals feel a little supportive factors and many inhibiting factors, then individuals tend to assume difficult behavior in him (Ajzen 2005).

Intention to use according to Ajzen and Fishbein (1991) is assumed to be a motivational factor that influences behavior. As a general rule, the stronger intention to engange in behavor, the more likely to have to show or do the behavior. Intention to use according to Hogg and Vaughan (2005) is an internal declaration to act or do something. In intention to use, $31.08 \%$ of respondents did not plan to have a pension fund and will not seek pension funds in old-age planning in the next few years. A total of $26.49 \%$ of respondents are not interested in having pension funds in old age planning in the next few years. The biggest reason respondents is not having the money to have a pension fund. In general, if an individual has the intention to conduct a behavior then the individual will tend to do the behavior, whereas if they do not have the intention to do behavior then the individual is not inclined to do this (Ajzen and Fishbein 1975).

\subsection{Analysis Fit Model}

The overall test of the model aims to evaluate in general the degree of goodness of fit between the data and the model. The overall goodness test criteria in this study were Khi-squared, p-value (significance test), RMSEA, GFI, AGFI, and CFI.

Table4. Analysis fit model

\begin{tabular}{|l|l|l|}
\hline \multicolumn{1}{|c|}{ Fit Model index } & \multicolumn{1}{c|}{ Value } & Result \\
\hline Chi-Square & 634.90 & Fit \\
\hline$p$-value & $0.34079 \geq 0.05$ & Fit \\
\hline RMSEA & $0.011 \leq 0.08$ & Fit \\
\hline GFI & 0.8594 & Marginal Fit \\
\hline AGFI & 0.823 & Fit \\
\hline NFI & 0.8459 & Marginal Fit \\
\hline CFI & 1.0000 & Fit \\
\hline
\end{tabular}

\subsection{Measurement Model Analysis}

Loading factor is the great closeness between the indicator variable with the latent variable. Indicators with high path coefficients have a higher contribution to explain latent variables. Most reference path coefficient values of 0.50 , the greater the path coefficient value will have strong enough validation to 
explain latent variables (Hair et al., 2009). The path model coefficient of measurement can be seen in Figure 3.

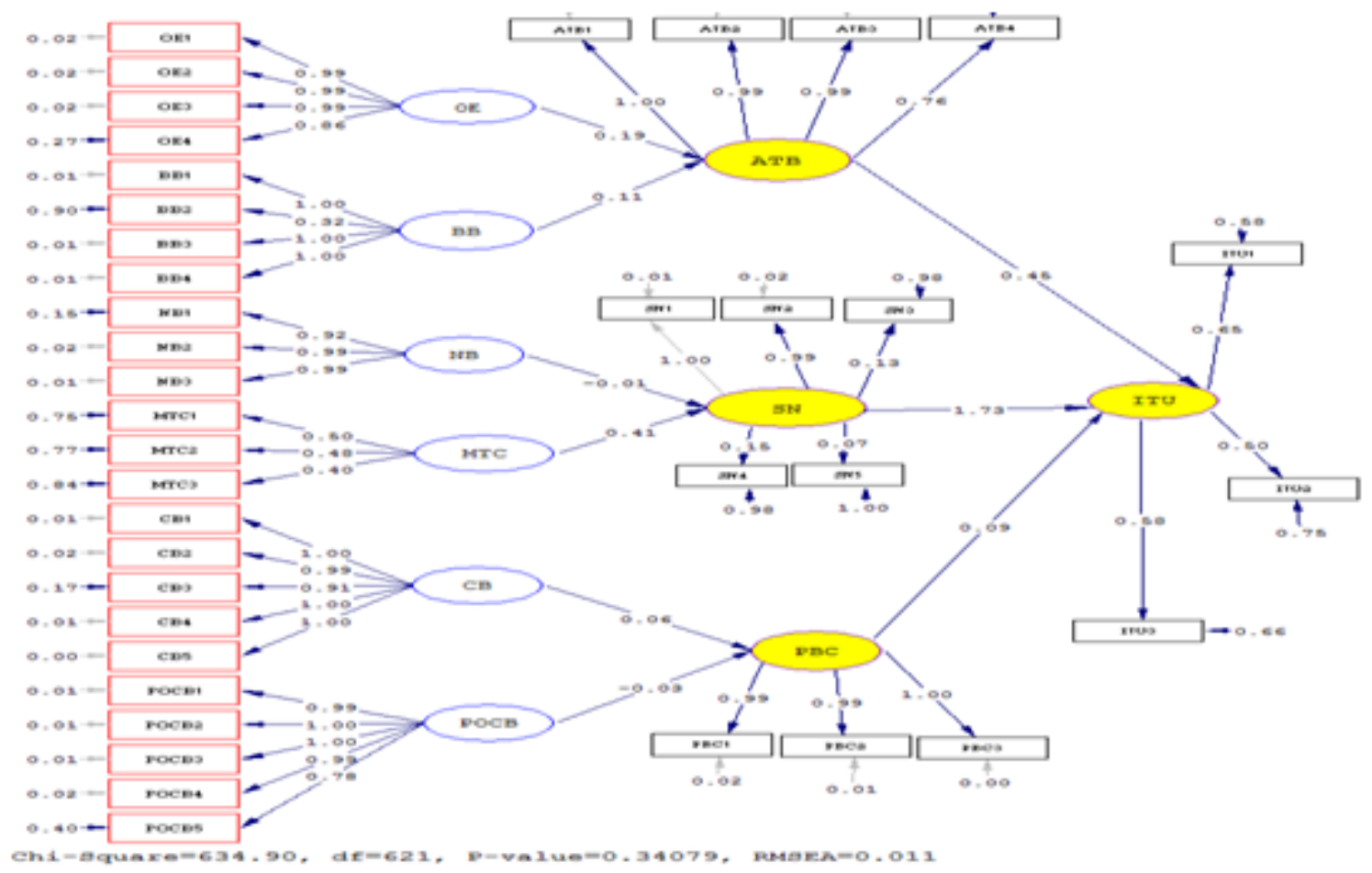

Figure3. Standardized loading factor on model

Figure3 can be simplified into the Coefficient of measurement model of each variable table in Table 4.Based on the results in Table 4, all valid indicator variables measure attitude toward behavior (ATB). ATB1 becomes the highest contribution to measure ATB. The indicator variables OE1, OE2, $\mathrm{OE} 3$, and $\mathrm{OE} 4$ are capable of measuring outcome evaluation (OE) variables. In variable behavioral beliefs (BB), BB3 variable is not valid enough in measuring BB. In the variable subjective norm (SN), the SN1 and SN2 variables are valid in measuring the latent variable SN. These results are consistent with Lunt and Livingstone (1991), Duflo and Saez (2002), and Hersey et al. (2010) that social support from family, partners, and peers has a positive impact on retirement planning. The indicator variables NB1, NB2, and NB3 are able to measure valid normative beliefs (NB). In the motivation to comply (MTC) variable, MTC1 variable is able to measure MTC variable validly but is low. The indicator variables $\mathrm{PBC} 1, \mathrm{PBC} 2$, and $\mathrm{PBC} 3$ are able to measure the variable of perceived behavioral control (PBC) variable validly. $\mathrm{PBC} 3$ contributes the highest in measuring PBC. Variables CB1, CB2, CB3, $\mathrm{CB} 4$, and $\mathrm{CB} 5$ are able to measure the latent variable control beliefs (CB) are valid. Variables POCB1, POCB2, PCB3, POCB4, and POCB5 are able to measure valid perceived of control beliefs (POCB). In the latent intention to use (ITU) variable, all indicator variables are able to measure ITU variables validly but are relatively low in the relationship. Variables that can not measure valid can occur because of having a low coefficient value or having a high error value.

Table4. Coefficient of measurement model of each variable

\begin{tabular}{|l|l|l|l|}
\hline \multicolumn{1}{|c|}{ Latent Variable } & $\begin{array}{c}\text { Loading } \\
\text { Factor }\end{array}$ & $\begin{array}{c}\text { Error } \\
\text { T- } \\
\text { Value }\end{array}$ \\
\hline Attitude Toward Of Behavior (ATB) & & & \\
\hline Retirement planning with pension funds is a good decision (ATB1) & 1.00 & 0.00 & 0.00 \\
Retirement planning with pension funds is something that needs to be decided & 0.99 & 0.02 & $14.59^{*}$ \\
(ATB2) & 0.99 & 0.02 & $14.54^{*}$ \\
Retirement planning with pension funds is an important thing to decide (ATB3) & 0.76 & 0.43 & $3.59^{*}$ \\
Retirement planning with with pension funds is a useful decision (ATB4) & & & \\
\hline Outcome Evaluation (OE) & & \\
\hline Increasing knowledge about pension funds is a good thing (OE1) & 0.99 & 0.02 & $19.81^{*}$ \\
Having a pension fund to ensure welfare in the retirement is good thing (OE2) & 0.99 & 0.02 & $19.76^{*}$ \\
Setting aside some salary to have a pension fund is a good thing (OE3) & 0.99 & 0.02 & $19.79^{*}$ \\
Trying to work harder to have a pension fund is a good thing (OE4) & 0.86 & 0.27 & $5.19^{*}$ \\
\hline Behavioral Beliefs (BB) & & & \\
\hline
\end{tabular}




\begin{tabular}{|c|c|c|c|}
\hline Preparing for retirement may help improve the knowledge of pension funds (BB1) & 1.00 & 0.01 & $20.02 *$ \\
\hline Preparing for retirement may help improve the knowledge of pension funds (BB2) & 0.32 & 0.90 & $4.79 *$ \\
\hline Preparing forretirement may help set aside some salary to have a pension fund & 1.00 & 0.01 & $19.94 *$ \\
\hline (BB3) & 1.00 & 0.01 & $20.02 *$ \\
\hline preparing for retiremen & & & \\
\hline \multicolumn{4}{|l|}{ Subjective Norm (SN) } \\
\hline There are others who require to join the Pension Fund (SN1) & 1.00 & 0.01 & 0.00 \\
\hline There are important people like family and relatives have pension funds (SN2) & 0.99 & 0.02 & $14.68 *$ \\
\hline People who interact daily have pension funds (SN3) & 0.13 & 0.98 & $2.38^{*}$ \\
\hline $\begin{array}{l}\text { The majority of people whose opinions are taken into account will receive } \\
\text { plans to have a pension fund (SN4) }\end{array}$ & 0.15 & 0.98 & $2.76^{*}$ \\
\hline Having a pension fund can make a pioneer in retirement planning (SN5) & 0.07 & 0.98 & 1.25 \\
\hline \multicolumn{4}{|l|}{ Normative beliefs (NB) } \\
\hline Families require to have pension funds in retirement planning (NB1) & 0.92 & 0.15 & $4.69 *$ \\
\hline Relatives require to have pension funds in retirement planning (NB2) & 0.99 & 0.02 & $19.65 *$ \\
\hline Coworkers require to have pension funds in retirement planning (NB3) & 0.99 & 0.01 & $19.81 *$ \\
\hline \multicolumn{4}{|l|}{ Motivation To Comply (MTC) } \\
\hline Families have an influence in deciding to have a pension fund (MTC1) & 0.50 & 0.75 & $6.14 *$ \\
\hline Relatives have an influence in determining the decision to have a pension fund & 0.48 & 0.77 & $5.87 *$ \\
\hline (MTC2) & 0.40 & 0.84 & $4.87 *$ \\
\hline $\begin{array}{l}\text { Coworkers have an influence in determining the decision to have a pension } \\
\text { fund (MTC2) }\end{array}$ & & & \\
\hline \multicolumn{4}{|l|}{ Perceived Behavioral Control (PBC) } \\
\hline having a Pension Fund is easy to do (PBC1) & 0.99 & 0.02 & 0.00 \\
\hline have a Pension Fund easily owned (PBC2) & 0.99 & 0.01 & $14.17 *$ \\
\hline Having a pension fund in old age planning is easy to decide (PBC3) & 1.00 & 0.00 & $14.01 *$ \\
\hline \multicolumn{4}{|l|}{ Control Beliefs (CB) } \\
\hline There are unexpected problems like demands in life (CB1) & 1.00 & 0.01 & $19.96^{*}$ \\
\hline Feeling sick, tired, listless (CB2) & 0.99 & 0.02 & $19.77 *$ \\
\hline There is a duty to the family asking for unexpected things in life (CB3) & 0.91 & 0.17 & $3.38 *$ \\
\hline There are unexpected demands on work or workplace (CB4) & 1.00 & 0.01 & $19.94 *$ \\
\hline There are unexpected financial problems in life (CB5) & 1.00 & 0.00 & $20.02 *$ \\
\hline \multicolumn{4}{|l|}{ Power of Control Beliefs (POCB) } \\
\hline $\begin{array}{l}\text { Unexpected problems such as demands in life make it more difficult to have a } \\
\text { pension fund (POCB1) }\end{array}$ & 1.00 & 0.01 & $19.89 *$ \\
\hline Feeling sick, tired, lethargic makes it harder to have a pension fund (POCB2) & 1.00 & 0.01 & $19.85^{*}$ \\
\hline $\begin{array}{l}\text { Responsibility on the family asking for unexpected things make it more } \\
\text { difficult to have a pension fund (POCB3) }\end{array}$ & 0.99 & 0.02 & $19.70 *$ \\
\hline $\begin{array}{l}\text { Unexpected demands on work or workplace make it more difficult to have a } \\
\text { pension fund (POCB4) }\end{array}$ & 0.78 & 0.40 & $2.76 *$ \\
\hline $\begin{array}{l}\text { The unexpected demands of financial problems in life will make it more } \\
\text { difficult to have a pension fund (POCB5) }\end{array}$ & 0.99 & 0.01 & $19.74 *$ \\
\hline \multicolumn{4}{|l|}{ Intention to Use (ITU) } \\
\hline Planning for retirement with pension funds to ensure old age may be planned & 0.65 & 0.66 & 0.00 \\
\hline (ITU1) & 0.50 & 0.75 & $5.21 *$ \\
\hline $\begin{array}{l}\text { Planning for retirement with pension funds may be sought (ITU2) } \\
\text { Interest to have a pension fund in retirement planning (ITU3) }\end{array}$ & 0.58 & 0.58 & $5.12 *$ \\
\hline
\end{tabular}

Description: (*) significant variable at $\alpha 0.05$

\subsection{Reliability Test}

Reliability test is an internal consistency measure of construct indicators that illustrates the extent to which common latent constructs (Hair et al. 1998). Validity is the extent to which indicators or variables accurately measure to be measured (Hair et al. 1998). Reliability test on questionnaire is done to measure the reliability of attribute in measuring latent variable by using CR and VE value. Variables are said to be reliable if the CR and VE values are at least 0.5 (Hair et al. 2009). Reliability of each variable in Model can be seen in Table 5. Based on the results in Table 5 shows the motivation to comply (MTC) variable can not be said reliable because it has CR value less than 0.5 that is equal to 0.446581 . The highest VE value is the variable perceived behavioral control (PBC) that is equal to 0.9867333 and the lowest $\mathrm{VE}$ is the intention to use (ITU) variable that is equal to 0.600634168 . Based on the results in Table 5 it can be seen that the variables SN, MTC, and ITU can not be said reliable because the VE value is less than 0.50 . 
Intention Model Analysis of Bogor Society against Pension Fund in Retirement Planning

Table5. Reliability of each Variable

\begin{tabular}{|l|l|l|}
\hline \multicolumn{1}{|c|}{ Variabellaten } & CR & VE \\
\hline Attitude Toward Of Behavior (ATB) & 0.967491146 & 0.884450 \\
\hline Outcome Evaluation (OE) & 0.977998386 & 0.919975 \\
\hline Behavioral Beliefs (BB) & 0.922191359 & 0.775600 \\
\hline Subjective Norm (SN) & 0.648337595 & 0.404880 \\
\hline Normative beliefs (NB) & 0.980186480 & 0.935533 \\
\hline Motivation To Comply (MTC) & 0.446581000 & 0.213466 \\
\hline Perceived Behavioral Control (PBC) & 0.996633147 & 0.986733 \\
\hline Control Beliefs (CB) & 0.991329479 & 0.961640 \\
\hline Power of Control Beliefs (POCB) & 0.980525887 & 0.913730 \\
\hline Intention to Use (ITU) & 0.600634168 & 0.336300 \\
\hline
\end{tabular}

\subsection{Structural Model Analysis}

The result of hypothesis test of latent variable of general model shows that not all relationship pattern on structural model is significant Figure4. Latent variables that have significant relationship pattern are outcome evaluation (OE) and behavioral beliefs (BB) toward attitude toward behavior (ATB), motivation to comply (MTC) against subjective norms (SN), control beliefs (CB) to perceived behavioral control ( PBC), and subjective norms (SN) of intention to use (ITU). Based on hypothesis test of latent variable of general model in Table 6, t-value result of ATB relationship to ITU $<1.96$ means attitude toward the behavior (attitude toward behavior) does not have significant influence to intention in interest of Bogor Society to Pension Fund in retirement planning. T-value of SN relationship to ITU accepted mean subjective norm (subjective norm) have significant influence to intention in interest of society of Bogor City to Pension Fund in retirement planning. These results are consistent with the research of Richard et al. (1994), Venkatesh and Davis (2000), Chalmers et al. (2008), Weiner and Doescher (2008), Croy et al. (2012), Grffin et al. (2012), and Brown and Laschever (2012). T-value of PBC relationship to ITU rejected means that perceived behavioral control does not have a significant influence on intention in Bogor Society against the Pension Fund in the retirement planning.

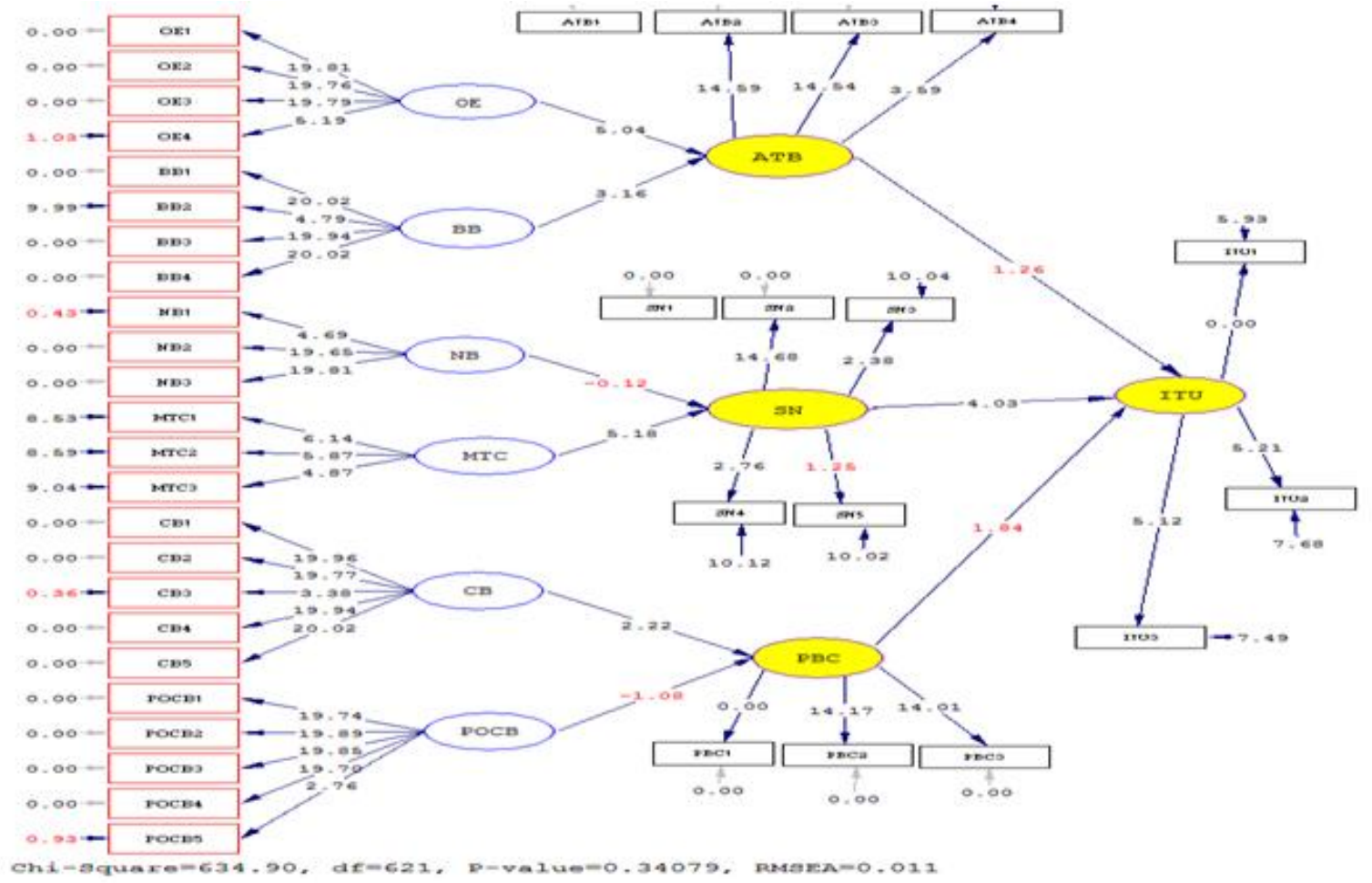

Figure6. T-Value on the Model

The value of loading factor in Table 6 shows the magnitude of the effect given between one variable against another. The intention of Bogor Society's interest towards pension fund in the retirement planning is most influenced by subjective norm (SN). The attitude toward behavior of the people of Bogor City to pension funds in old age planning (ATB) is most influenced by outcome evaluation 
(OE). The value of outcome evaluation (OE) is directly proportional to attitudes toward behavior (ATB).

Table6. Hypothesis test of latent model variables

\begin{tabular}{|l|c|c|}
\hline \multicolumn{1}{|c|}{ Relationship } & Loading Factor & T-VALUE \\
\hline $\mathrm{OE} \rightarrow$ ATB & 0.19 & $5.04^{*}$ \\
\hline $\mathrm{BB} \rightarrow \mathrm{ATB}$ & 0.11 & $3.16^{*}$ \\
\hline $\mathrm{NB} \rightarrow \mathrm{SN}$ & -0.01 & -0.12 \\
\hline $\mathrm{MTC} \rightarrow \mathrm{SN}$ & 0.41 & $5.18^{*}$ \\
\hline $\mathrm{CB} \rightarrow \mathrm{PBC}$ & 0.06 & $2.22^{*}$ \\
\hline $\mathrm{POCB} \rightarrow \mathrm{PBC}$ & -0.03 & -1.08 \\
\hline $\mathrm{ATB} \rightarrow \mathrm{ITU}$ & 0.45 & -1.26 \\
\hline $\mathrm{SN} \rightarrow \mathrm{ITU}$ & 1.73 & $4.03^{*}$ \\
\hline $\mathrm{PBC} \rightarrow$ ITU & 0.09 & 1.84 \\
\hline
\end{tabular}

$\mathrm{ITU}=0.45 * \mathrm{ATB}+1.73 * \mathrm{SN}+0.09 * \mathrm{PBC}$

with:

$\mathrm{ATB}=0.19 * \mathrm{OE}+0.11 * \mathrm{BB}$

$\mathrm{SN}=-0.01 * \mathrm{NB}+0.41 * \mathrm{MTC}$

$\mathrm{PBC}=0.06 * \mathrm{CB}-0.03 * \mathrm{POCB}$

\section{CONCLuSion}

Most of the people of Bogor City do not have pension funds in the retirement planning. Bogor City citizens who do not have a pension fund have a reason not to have the budget to be allocated to the pension fund although retirement planning with pension funds is a good decision, important, necessary to decide, and useful. Respondents interest model of pension funds in retirement planning with the theory planned of behavior produce a pretty good model. The p-value and RMSEA values can be said fit the model criteria. Reliability test results show that almost all CR values are reliable in measuring hypothesized latent variables.

The pattern of relationships generated by the model in general shows that the intention of Bogor City to pension funds in the retirement planning is influenced by subjective norms. Attitudes toward behavior (ATB) to respondent decisions have pension funds in old age planning influenced by outcome evaluation (OE) and behavioral belief (BB). The subjective norm (SN) is influenced by motivation to comply (MTC). Behavior control (PBC) is influenced by control beliefs (CB).

\section{REFERENCES}

[1] Abrahamse W., and Steg L., 2009. How do Socio-Semographic and Psychological Factors Relate to Households's Direct and Indirect Energy Use and Savings?. Journal of Economic Psychology, 30: 711720, https:doi.org./10/1016/j/joep.2009.05.006.

[2] Ajzen I., 1985. From Intentions to Action: A Theory of Planned Behavior. New York (US): Springer.

[3] Ajzen I., 2005. Attitudes, Personality, and Behavior. $2^{\text {nd }}$ Edition. Berkshire: New York (US) : McGrawHill, Inc.

[4] Ajzen I., 2006. Constructing a TPB Quistionnnaire: Conceptual and Methodological Considerations. Tersedia dari: http://www.unix.oit.umass.edu/tpb.measurement.pdf.

[5] Amelia R., Hartoyo., and Suharjo B., 2017. Kepemilikan perencanaan keuangan hari tua pada pekerja Kota Bogor. Jurnal Ilmiah Manajemen. 7:97-112.

[6] Brown K. M., and Laschever R. A., 2012. When They;re Sixty-Four: Peer Effects and the Timing of Retirement. American Economic Journal: Applied Economics, 4: 90-115. doi:10.1257/app.4.3.90.

[7] Chalmers J., Johnson W., and Reuter J., 2008. Who Determines when You Retire? Peer Effects and Retirement. National Bureau of Economic Research. Akses dari http://www.nber.org/aging/rrc/papers/ onb08-13.pdf.

[8] Clark RL., Morril M. S., and Allen S. G., 2012. The Role of Financial Literacy in Determining Plans. Economic Inquiry, 50(4).

[9] Croy G., Gerrans P., and Speelman C., 2010a. The Role and Relevance of Domain Knowledge, Perceptions of Planning Importance, and Risk Tolerance inPredicting Saving Intentions. Journal of Economic Psychology, 31: 860-871. doi:10.1016/j.joep.2010.06.002. 
[10] Croy G., Gerrans P., and Speelman C. 2012. Normative Influence on Retirement Saving Decisions: Do People Care what Employers and the Goverment want?. Australian Journal of Psychology, 64: 83-91. doi:10.1111/j.1742-9536.2011.00029x.

[11] Duflo E., and Saez E., 2002. Participation and Investment Decisions in a Retirement Plan: The Influence of Colleagues's Choices. Journal of Public Economics, 85: 121 - 148. doi:10.1016/S0047-2727(01)00098-6.

[12] Fishbein M., and Ajzen I., 1975. Belief, Attitude, Intention, and Behavior: An Introduction to Theory and Research. Tersedia dari: http://people.unmass,edu/aizen/fdana1975.html.

[13] Griffin B, D Loe, and Hesketh B. 2012. Using Proactivity, Time Discounting, and the Theory of Planned Behavior to Identify Predictors of Retirement Planning. Educational Gerontology. 38: 877-889.

[14] Grover H and Vernekar SS. 200. Review on Facors Influencing Investor's Wealth Management Behavior. The International Journal of Business and Management. Volume 3 Issue 4.

[15] Hair JF, Anderson RE, Tatham RL and Black WC. 1995. Multivariate Data Analysis with Reading $4^{\text {th }}$ Edition. New Jersey: Prentice-Hall, Inc.

[16] Hair JF, Black WC, Babin BJ, and Anderson RE. 2009. Multivariate Data Analysis $7^{\text {th }}$ Edition. Boston (US): Pearson.

[17] Hershey DA, Henkens K, and Van DHP. 2010. Aging and Financial Planning for Retirement: Interdisciplinary Influences Viewed through a Cross-Cultural Lens. Internation Journal of Aging and Human Development, 70: 1 - 38. doi:10.2190/AG.70.1.a.

[18] Hogg MA and Vaughan GM. 2005. Introduction to Scocial Psychology. $4^{\text {th }}$ Ed. Australia: Prentice Hall.

[19] Joo SH and Grable JE. 2005. Employee Education and the Likelihood of Having a Retirement Savings Program. Finanial Counseling and Planning. 16: 37-49.

[20] Kim VKG. 2003. An Empirical Study of Older Workers's Attitudes Towards the Retirement Experience. Employee Relation. 25(4):330-346.

[21] Kimiyaghalam F, Mansori S, and Safari M. 2017. The Effects of Behavioral Factors on Retirement Planning in Malaysia.

[22] Koposko JL, Kiso H, Hershey DA, and Gerrans P. 2015. Percptive of Retirement Savings Relative to Peers. Work, Aging, and Retirement. Doi:10.1093/workar/wav019.

[23] Lunt PK and Livingstone SM. 1991. Psychological, Social, and Economic Determinants of Saving: Comparing Recurrent and Total Savings. Journal of Economic Psychology, 12: 621 - 641. doi:10.1016/0617-4870(91)90003-C.

[24] Lusardi A. 2008. Household Saving Behaviour: The Role of Financial Literacy, Information, and financial Educations Programs. NBER Working Paper No 13824, 1-43.

[25] Lusardi A and Mitchell OS. 2007. Financial Literacy and Retirement Preparedness: Evidence and Implications for Financial Education. Business Economics.

[26] Lusardi A and Mitchell OS. 2007. Baby Boomer Retirement Security: The Roles of Planning, financial Literacy, adn Housing Wealth. Journal of Monetary Economics. 54(1): 205-224.

[27] Lusardi A and Mitchell OS, Curto V. 2010. Financial Literacy among the young. Journal of Consumer Affairs, 44(2): 358-380. Doi:10.1111/j.1745-6606.2010.01173x.

[28] Lusardi A and Mitchell OS. 2011. Financial Literacy dan Retirement Planning in the United States. Journal of Pension Economics andFinance. 10: 509-525. Doi:10.1017/S147474721100045x.

[29] Lusardi A and Mitchell OS. 2014. The Economic Importance of Financial Literacy: Theory and Evidence. Journal of Economic Literature, 52: 5-44.

[30] Mohidin R, Jamal AAA, Geetha C, Sang LT, and Karim MRA. 2013. Revisiting the Relationship Between Attitudes and Retirement Planning Behaviour: A Study on Personal Financial Planning. International Journal of Multidisciplinary Thought. 3(2):449-461.

[31] Mutran EJ, Reitzes DC, and Fernandez ME. 1997. Factors that Influence Attitudes toward Retirement. Research on Aging. 19: 251-273 .

[32] Noone JH, Stephens C, and Alpass FM. 2009. Preretirement Planning and Well-being in Later Life: A Prospective Study. Research on Aging. 31:295-317.

[33] Prawitz AD and Cohart J. 2014. Workplace Financial Education Facilitates Improvement in Personal Financial Behaviors. Journal of Financial Counseling and Planning

[34] Richard L, Dedobbeler N, Champagne F, and Potvin L. 1994. Predicting Child Restraint Device Use: A Comparison of Two Models. Journal of Applied Social Phsycology, 24: 1837-1847.

[35] Satsios N and Hadjidakis S. 2018. Applying the Theory of Planned Behavior (TPB) in Saving Behaviour of Pomak Households. International Journal of Financial Research, 0(2):122-133. 
[36] Topa G, Moriano JA, Depolo M, Alcover CM, and Morales JF. 2009. Antecedents and consequences of Retirement Planning and Decision Making: a meta-analysis and Model. Journal of Vocational Behavior. 75: 38-55.

[37] Venkatesh V and Davis FD. 2000. A Theorical Expansion of the Technology Acceptance Model: four Longitudinal Field Studies. Management Science, 46(2): 186 - 204. Doi: 10.1287/mnsc.46.2.186.11926

[38] [BPS] BadanPusatStatistik. 2016. AngkatanKerja di atasUmur 15 tahun [internet]. [diacu 2017 Januari 18]. Tersediadari: https://www.bps.go.id/linkTabelStatis/ view/id/1909.

[39] [OJK] OtoritasJasaKeuangan. 2017. BukuStatistik Dana PensiunTahun 2015 [internet]. [diacu 2017 Januari 18]. Tersediadari: http://www.ojk.go.id/id/ kanal/iknb/data-dan-statistik/Dana-pensiun/ Default. aspx.

[40] [UU] Undang-UndangRepublik Indonesia. 1992. Undang-UndangRepublik Indonesia Nomor 11 Tahun 1992 tentang Dana Pensiun.

[41] [UU] Undang-UndangRepublik Indonesia. 2003. Undang-UndangRepublik Indonesia Nomor 13 Tahun 2003 tentangKetenagakerjaan.

Citation: Putri Putu Pratami et.al. “Intention Model Analysis of Bogor Society against Pension Fund in Retirement Planning" International Journal of Managerial Studies and Research (IJMSR), vol 6, no. 9, 2018, pp. 15-30. doi:http://dx.doi.org/10.20431/2349-0349.0609002.

Copyright: (c) 2018 Authors. This is an open-access article distributed under the terms of the Creative Commons Attribution License, which permits unrestricted use, distribution, and reproduction in any medium, provided the original author and source are credited. 